\title{
Paired Mesoderm Homeobox Protein 1
}

National Cancer Institute

\section{Source}

National Cancer Institute. Paired Mesoderm Homeobox Protein 1. NCI Thesaurus. Code C98032.

Paired mesoderm homeobox protein 1 (245 aa, $\sim 27 \mathrm{kDa}$ ) is encoded by the human PRRX1 gene. This protein plays a role in muscle development from mesodermal precursors. 